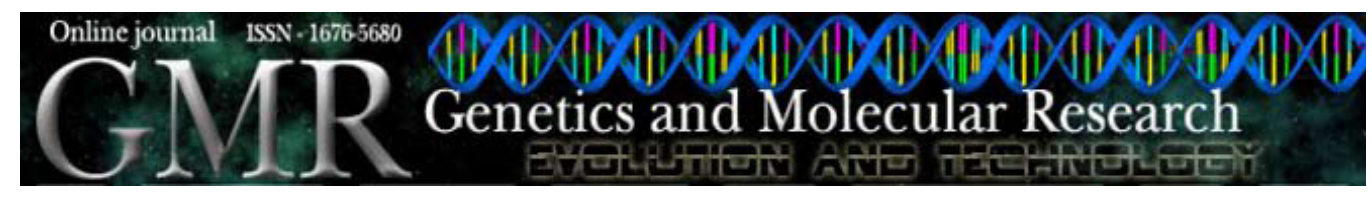

\title{
Flow cytometry for diepoxybutane test analysis
}

\author{
C.F.A. Moreira ${ }^{1}$ L.C. Brito Júnior ${ }^{1,2}$ and J.A.R. Lemos ${ }^{1,2}$ \\ ${ }^{1}$ Universidade Federal do Pará, Instituto de Ciências Biológicas, \\ Belém, PA, Brasil \\ ${ }^{2}$ Centro de Hemoterapia e Hematologia do Pará, Belém, PA, Brasil \\ Corresponding author: J.A.R. Lemos \\ E-mail: lemos@ufpa.br
}

Genet. Mol. Res. 7 (4): 1353-1359 (2008)

Received September 8, 2008

Accepted October 3, 2008, 2008

Published December 2, 2008

\begin{abstract}
The main feature of Fanconi anemia (FA) is the high sensitivity of the cells to the clastogenic agent, diepoxybutane (DEB). Thus, differential diagnosis of this syndrome can be made by cytogenetic analysis; adding DEB to lymphocytes in culture (DEB test) increases the number of chromosome breaks. Fanconi anemia cells have an abnormal cell cycle, with an increased frequency of cells arrested at G2. In order to determine if flow cytometry can be utilized for FA diagnosis, we cultivated lymphocytes with DEB and analyzed them for G2 accumulation. Lymphocytes cultivated for $72 \mathrm{~h}$ were labeled with CD3 antibody and propidium iodide for analysis of the cells in the G2 phase. Cultures of lymphocytes from two FA patients who were diagnosed by the DEB test and six control individuals with a negative DEB test had 55.26\% (SD \pm $6.97)$ and $2.81 \%(\mathrm{SD} \pm 0.22)$ cells arrested at $\mathrm{G} 2$, respectively. We
\end{abstract}


conclude that flow-cytometry analysis of cells exposed to DEB can be useful for FA diagnosis.

Key words: Diepoxybutane test; Flow cytometry; Cell cycle; Fanconi anemia

\section{INTRODUCTION}

Fanconi anemia (FA) was described in 1927, by a Swiss pediatrician named Guido Fanconi, and its prevalence is about 1 to 5 per million (Fanconi, 1927; Swift, 1971; Schroeder et al., 1976; Kook et al., 1998; Auerbach et al., 2001; Joenje and Patel, 2001). FA is an autosomal recessive disease, characterized by congenital bone abnormalities, cutaneous manifestations of diffuse hyperpigmentation and café-au-lait spots, bone marrow failure, chromosomal instability, hypersensitivity of the DNA to clastogenic agents, and predisposition to cancer (Alter, 2003; Bagby Jr., 2003).

The important feature of FA patients that distinguishes this disease from other syndromes is the extreme sensitivity of FA cells to agents that produce DNA cross links, such as mitomycin C (MMC) and diepoxybutane (DEB) (Auerbach and Wolman, 1976).

Auerbach et al. (1981) introduced a method for postnatal and prenatal diagnosis of FA patients, called the DEB test, and considered the gold standard test for FA diagnosis (German et al., 1987; Auerbach, 1988; Dokal, 2000).

DNA repair that occurs in the G2 phase is related to revision and DNA repair before progression to mitosis (Heinrich et al., 1998; Taniguchi and D'Andrea, 2006). Many studies have demonstrated that repair in the G2 phase of FA cells is later than in cells from control groups (Sasaki, 1975; Dutrillaux et al., 1982; Kubbies et al., 1985; Seyschab et al., 1993; Akkari et al., 2001). FA cells in G2 arrest are increased when they are exposed to clastogenic agents or high oxygen tension (Dutrillaux et al., 1982; Hoehn et al., 1989). This fact can be explained by the fact that these cells fail to carry out the DNA repair and therefore remain in the G2 phase of cell cycle (Tischkowitz and Hodgson, 2003).

Flow cytometry can be used to identify FA cells exposed to clastogenic agents by quantification of their arrested frequency in the G2 phase of the cell cycle, with the same efficiency of cytogenetics (Schindler et al., 1985; Berger et al., 1993; Seyschab et al., 1995). In the literature, two clastogenic agents are used for FA cell cycle analysis, MMC and nitrogen mustard (Dean and Fox, 1983; Miglierina et al., 1991; Berger et al., 1993; Heinrich et al., 1998).

Flow cytometry has more advantages over cytogenetics because it is faster and allows the analysis of up to 10,000 cells. This method can also be useful in cases of somatic mosaicism, demonstrated by some FA patients (Toraldo et al., 1998).

In order to demonstrate that the flow cytometry can be utilized in the diagnosis of the FA, we present here the application of this method in the analysis of lymphocytes cultivated with DEB arrested in G2 phase.

\section{MATERIAL AND METHODS}

\section{Study design}

Peripheral blood samples from two FA patients were collected and sent to the Labo- 
ratório de Biologia Celular e Molecular do Centro de Hemoterapia e Hematologia do Pará (HEMOPA), Brazil. In order to identify the FA patients, we applied the DEB test according to Auerbach et al. (1981). For the validation of the cell cycle analysis of the DEB tests by flow cytometry, six samples from normal individuals were prepared and analyzed in the same way.

\section{Cell culture and cytogenetic analysis}

Cultures of $72 \mathrm{~h}$ for each sample were carried out. The PB-MAX ${ }^{\mathrm{TM}}$ (Gibco) karyotyping medium was used, and the cells were stimulated by phytohemagglutinin. After $24 \mathrm{~h}$, DEB was added at a final concentration of $0.1 \mu \mathrm{g} / \mathrm{mL}$ culture medium.

For each individual, four cultures were performed, two of them for cytogenetic analysis and two for flow cytometry. DEB was added to one of each of the two culture flasks.

At the end, $0.2 \mathrm{~mL}$ colcemid $(0.0016 \%)$ was added to all flasks for cytogenetic analysis, for $2 \mathrm{~h}$. Next, hypotonic solution $(0.075 \mathrm{M} \mathrm{KCl})$ was added for $25 \mathrm{~min}$, and afterward, the cells were submitted to acetic acid-methanol (3:1) treatment. The cell suspension was dropped on the slides and dried at room temperature. Fifty Giemsa-stained metaphases were analyzed for each patient. The DEB test was considered to be positive in the ones with values higher than 1.06 breaks/cell (Auerbach et al., 1989).

\section{Cell cycle analysis}

After $72 \mathrm{~h}$ of culture, the cell suspension was collected and centrifuged, and the supernatant was discarded. The pellet was resuspended in $1 \mathrm{~mL}$ RPMI medium. One hundred microliters was colleted from each culture flask and divided as follow: $10 \mu \mathrm{L}$ was added to two flasks with CD45 PE-Cy5 antibody (BD Pharmigen ${ }^{\mathrm{TM}}$ ), and $10 \mu \mathrm{L}$ to two flasks with CD3 FITC antibodies (BD Pharmigen ${ }^{\mathrm{TM}}$ ) and propidium iodide-staining solution (BD Pharmi$\mathrm{gen}^{\mathrm{TM}}$ ). Afterward, 10,000 cells were acquired, and the cell cycle was analyzed by CellQuest ${ }^{\mathrm{TM}}$ $P R O$ for MacIntosh in the FACS Calibur (BD - Biosciences).

\section{Data analysis}

The cell cycle data from flow cytometry were presented as the percentage of cells arrested in G2 phase. The values of average, minimum and maximum and standard deviation were presented as descriptive statistic. The samples were analyzed by a bootstrap $t$-test using the BioEstat 4.0 software, assuming $\mathrm{P}<0.05$ as the level of significance (Ayres et al., 2005).

\section{RESULTS}

The two patients who presented clinical characteristics of FA were diagnosed as FA patients by the DEB test. One patient had 8.3 breaks/cell, and the other had 3.2 breaks/cell. The individuals from the control group showed a negative DEB test, with values less than 1.06 breaks/cell that varied between 0 and 0.04 breaks/cell.

The FA patients showed an average of 55.26 and $33.02 \%$ of cells arrested in the G2 phase with and without DEB, respectively. The six individuals from the control group showed 
average values between 1.89 and $2.82 \%$ of cells blocked in the G2 phase in the presence and absence of DEB, respectively (Figure 1 and Table 1).

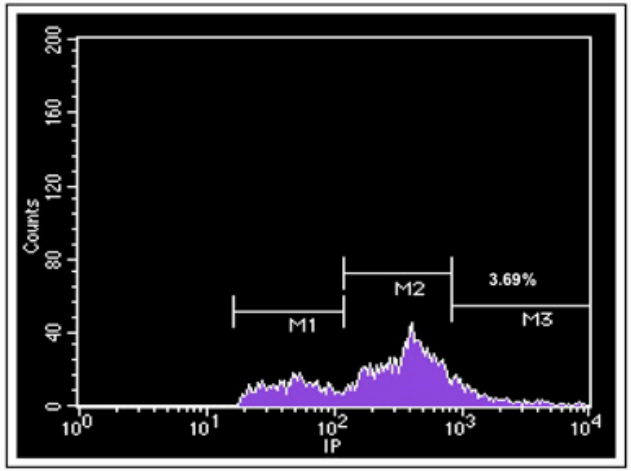

A. DEB control group

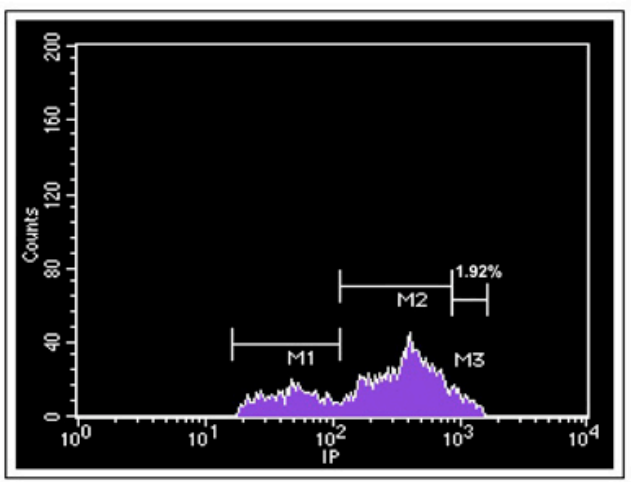

B. No DEB control group

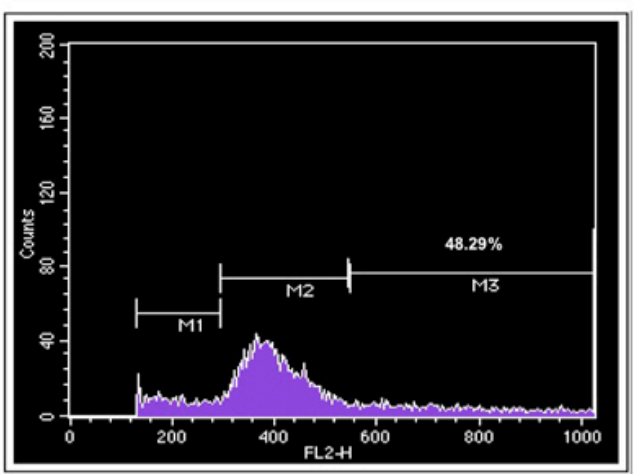

C. DEB FA patient

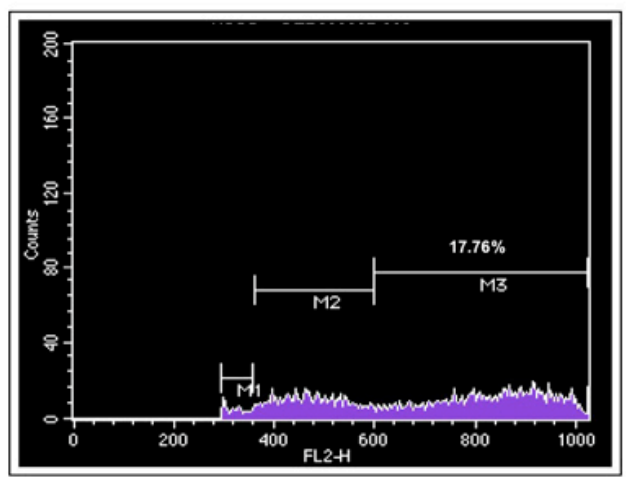

D. No DEB FA patient

Figure 1. Cell cycle analysis of Falconi anemia (FA) patients (C and D) and control group (A and B), with (A and C) and without (B and D) diepoxybutane (DEB), showing high frequency $(48.29 \%$ ) of cells blocked in the G2 phase (C). High accumulation of cells in G2 phase is seen in FA patients with and without DEB (C and D). M1: G1 phase; M2: S phase; M3: G2 phase.

Table 1. Results with averages and standard deviation of the analysis by flow cytometry of the two groups and comparison between experiments with and without diepoxybutane (DEB).

\begin{tabular}{|c|c|c|c|c|c|}
\hline \multirow[t]{2}{*}{ Sample (N) } & \multicolumn{2}{|c|}{ No DEB } & \multicolumn{2}{|c|}{ DEB } & \multirow[t]{2}{*}{$\mathrm{P}(* \mathrm{P})$} \\
\hline & Mean \pm SD & Min and Max values & Mean \pm SD & Min and Max values & \\
\hline Control (6) & $1.89 \pm 0.02$ & $1.83-1.94$ & $2.81 \pm 0.22$ & $1.97-3.69$ & $0.009(* 0.003)$ \\
\hline FA patients (2) & $33.02 \pm 15.26$ & $17.76-48.29$ & $55.26 \pm 6.97$ & $48.29-62.23$ & - \\
\hline
\end{tabular}

*P value by bootstrap for 10,000 simulations. $\mathrm{FA}=$ Falconi anemia. 


\section{DISCUSSION}

The advent of the DEB test was an important advance for the diagnosis of FA: before it, the establishment of the diagnosis was only possible based on congenital abnormalities and bone marrow failure, which is not sufficient, because some patients do not show physical abnormalities (Fanconi, 1927; Giampietro et al., 1997; Taylor, 2001).

Some studies have demonstrated that the addition of clastogenic agents to cell cultures of FA patients could make the diagnosis more specific using flow cytometry, such as with MMC or nitrogen mustard. For this, the mononuclear cells are separated by FicollHypaque gradient and stained with Hoechst (Dean and Fox, 1983; Miglierina et al., 1991; Heinrich et al., 1998; Berger et al., 1993; Bechtold et al., 2006).

The use of CD3 antibody was satisfactory for labeling T lymphocytes. This procedure dispenses with the methods for separation of mononuclear cells, such as FicollHypaque, making the method described here faster and easy to perform. The use of propidium iodide was shown to be as efficient as Hoechst stain (Graham and Fox, 1983).

The DEB has the property of causing damages and cross-links in DNA, which lead cells to stop in phases of repair, more specifically in the G2 phase (Sasaki and Tonomura, 1973; Auerbach and Wolman, 1976; Johnstone et al., 1997; Freie et al., 2004; Niedernhofer et al., 2005). The analysis of the control group and FA patients revealed that such fact is true, because these groups also showed variations in the concentration of cells in the G2 phase, in cultures with DEB. The control group had an average of about $1.89 \%$ of cells arrested in G2 phase; such result does not resemble that in the FA patients who had $33.02 \%$ of cells arrested in G2 (Kaiser et al., 1982; Seyschab et al., 1995).

To the best of our knowledge, this is the first time that this technique of analysis of the cell cycle has been used, which was shown to be efficient, besides being fast and useful. The use of DEB in the cell cultures, besides being specific for the diagnosis of FA, is also efficient and much safer, when compared to the use of nitrogen mustard. DEB is more specific than MMC, and MMC still can show false positives due to the great number of variations of results seen in normal individuals (Auerbach et al., 1989).

Cell cycle analysis by flow cytometry in this study was demonstrated as being as precise as cytogenetic analysis for the diagnosis of FA, corroborating finding in the literature that the accumulation of cells in the G2 phase constitutes a powerful tool for the diagnosis of the FA, using lymphocytes cultivated with DEB (Miglierina et al., 1990; Bechtold et al., 2006).

Both FA patients diagnosed in this study displayed the typical characteristics of chromosomal breaks and the accumulation of cells in the G2 phase, which have also been observed in FA patients in other studies in the literature. Thus, the proteins that play some role in the alteration of the cell cycle in FA patients can be the same involved in the response to DNA damage disclosed by cells blocked in G2 (Pichierri and Rosselli, 2004; Freie et al., 2004; Howlett et al., 2005).

Thus, cell cycle analysis by flow cytometry of lymphocytes from FA patients, cultivated in the presence of DEB, was shown to be as efficient as cytogenetic analysis (DEB test), indicating that the DEB test can also be performed using flow cytometry, allowing the diagnosis of FA by the technique described in this paper. 


\section{REFERENCES}

Akkari YM, Bateman RL, Reifsteck CA, D'Andrea AD, et al. (2001). The 4N cell cycle delay in Fanconi anemia reflects growth arrest in late S phase. Mol. Genet. Metab. 74: 403-412.

Alter BP (2003). Inherited Bone Marrow Failure Syndromes. In: Nathan and Oski's Hematology of Infancy and Childhood (Nathan DG, Orkin SH, Ginsburg D and Look AT, eds.). Saunders, Philadelphia, 280-365.

Auerbach AD (1988). A test for Fanconi's anemia. Blood 72: 366-367.

Auerbach AD and Wolman SR (1976). Susceptibility of Fanconi's anaemia fibroblasts to chromosome damage by carcinogens. Nature 261: 494-496.

Auerbach AD, Adler B and Chaganti RS (1981). Prenatal and postnatal diagnosis and carrier detection of Fanconi anemia by a cytogenetic method. Pediatrics 67: 128-135.

Auerbach AD, Rogatko A and Schroeder-Kurth TM (1989). International Fanconi Anemia Registry: relation of clinical symptoms to diepoxybutane sensitivity. Blood 73: 391-396.

Auerbach AD, Buchwald M and Joenje H (2001). The Metabolic and Molecular Bases of Inherited Disease. McGraw-Hill, New York, 753-768.

Ayres M, Ayres M Jr, Ayres DL and Santos AS (2005). BioEstat 5.0: Aplicações Estatísticas nas Áreas das Ciências Biológicas e Médicas. 5th edn. Instituto de Desenvolvimento Sustentável Mamirauá - IDSM/MCT/CNPq, Belém.

Bagby GC Jr (2003). Genetic basis of Fanconi anemia. Curr. Opin. Hematol. 10: 68-76.

Bechtold A, Friedl R, Kalb R, Gottwald B, et al. (2006). Prenatal exclusion/confirmation of Fanconi anemia via flow cytometry: a pilot study. Fetal Diagn. Ther. 21: 118-124.

Berger R, Le Coniat M and Gendron MC (1993). Fanconi anemia. Chromosome breakage and cell cycle studies. Cancer Genet. Cytogenet. 69: 13-16.

Dean SW and Fox M (1983). Investigation of the cell cycle response of normal and Fanconi's anaemia fibroblasts to nitrogen mustard using flow cytometry. J. Cell Sci. 64: 265-279.

Dokal I (2000). The genetics of Fanconi's anaemia. Baillieres Best. Pract. Res. Clin. Haematol. 13: 407-425.

Dutrillaux B, Aurias A, Dutrillaux AM, Buriot D, et al. (1982). The cell cycle of lymphocytes in Fanconi anemia. Hum. Genet. 62: 327-332.

Fanconi G (1927). Familiaere infantile perniziosaartige Anaemie (pernizioeses Blutbild und Konstitution). Jahrbuch Kinderheild 117: 257-280.

Freie BW, Ciccone SL, Li X, Plett PA, et al. (2004). A role for the Fanconi anemia C protein in maintaining the DNA damage-induced G2 checkpoint. J. Biol. Chem. 279: 50986-50993.

German J, Schonberg S, Caskie S, Warburton D, et al. (1987). A test for Fanconi’s anemia. Blood 69: 1637-1641.

Giampietro PF, Verlander PC, Davis JG and Auerbach AD (1997). Diagnosis of Fanconi anemia in patients without congenital malformations: an international Fanconi Anemia Registry Study. Am. J. Med. Genet. 68: 58-61.

Graham A and Fox M (1983). The role of suppression of DNA synthesis and inhibition of cell cycle progression in cellular sensitivity to alkylation damage. Carcinogenesis 4: 269-274.

Heinrich MC, Hoatlin ME, Zigler AJ, Silvey KV, et al. (1998). DNA cross-linker-induced G2/M arrest in group C Fanconi anemia lymphoblasts reflects normal checkpoint function. Blood 91: 275-287.

Hoehn H, Kubbies M, Schindler D, Poot M, et al. (1989). BrdU-Hoechst Flow Cytometry Links the Cell Kinetic Defect of Fanconi Anaemia to Oxygen Hypersensitivity. In: Fanconi Anaemia: Clinical, Cytogenetic and Experimental Aspects (Schroeder-Kurth TM, Auerbach AD and Obe G, eds.). Springer-Verlag, Berlin, 162-173.

Howlett NG, Taniguchi T, Durkin SG, D'Andrea AD, et al. (2005). The Fanconi anemia pathway is required for the DNA replication stress response and for the regulation of common fragile site stability. Hum. Mol. Genet. 14: 693-701.

Joenje H and Patel KJ (2001). The emerging genetic and molecular basis of Fanconi anaemia. Nat. Rev. Genet. 2: 446-457.

Johnstone P, Reifsteck C, Kohler S, Worland P, et al. (1997). Fanconi anemia group A and D cell lines respond normally to inhibitors of cell cycle regulation. Somat. Cell Mol. Genet. 23: 371-377.

Kaiser TN, Lojewski A, Dougherty C, Juergens L, et al. (1982). Flow cytometric characterization of the response of Fanconi's anemia cells to mitomycin C treatment. Cytometry 2: 291-297.

Kook H, Cho D, Cho SH, Hong WP, et al. (1998). Fanconi anemia screening by diepoxybutane and mitomicin C tests in Korean children with bone marrow failure syndromes. J. Korean Med. Sci. 13: 623-628.

Kubbies M, Schindler D, Hoehn H, Schinzel A, et al. (1985). Endogenous blockage and delay of the chromosome cycle despite normal recruitment and growth phase explain poor proliferation and frequent edomitosis in Fanconi anemia cells. Am. J. Hum. Genet. 37: 1022-1030.

Miglierina R, Le Coniat M, Gendron M and Berger R (1990). Diagnosis of Fanconi's anemia by flow cytometry. Nouv. Rev. Fr. Hematol. 32: 391-393. 
Miglierina R, Le Coniat M and Berger R (1991). A simple diagnostic test for Fanconi anemia by flow cytometry. Anal. Cell Pathol. 3: 111-118.

Niedernhofer LJ, Lalai AS and Hoeijmakers JH (2005). Fanconi anemia (cross)linked to DNA repair. Cell 123: 1191-1198.

Pichierri P and Rosselli F (2004). Fanconi anemia proteins and the S phase checkpoint. Cell Cycle 3: 698-700.

Sasaki MS (1975). Is Fanconi's anaemia defective in a process essential to the repair of DNA cross links? Nature 257: 501-503.

Sasaki MS and Tonomura A (1973). A high susceptibility of Fanconi's anemia to chromosome breakage by DNA crosslinking agents. Cancer Res. 33: 1829-1836.

Schindler D, Kubbies M, Hoehn H, Schinzel A, et al. (1985). Presymptomatic diagnosis of Fanconi's anaemia. Lancet 1: 937.

Schroeder TM, Tilgen D, Kruger J and Vogel F (1976). Formal genetics of Fanconi's anemia. Hum. Genet. 32: 257-288.

Seyschab H, Sun Y, Friedl R, Schindler D, et al. (1993). G2 phase cell cycle disturbance as a manifestation of genetic cell damage. Hum. Genet. 92: 61-68.

Seyschab H, Friedl R, Sun Y, Schindler D, et al. (1995). Comparative evaluation of diepoxybutane sensitivity and cell cycle blockage in the diagnosis of Fanconi anemia. Blood 85: 2233-2237.

Swift M (1971). Fanconi's anaemia in the genetics of neoplasia. Nature 230: 370-373.

Taniguchi T and D'Andrea AD (2006). Molecular pathogenesis of Fanconi anemia: recent progress. Blood 107: 4223-4233.

Taylor AM (2001). Chromosome instability syndromes. Best Pract. Res. Clin. Haematol. 14: 631-644.

Tischkowitz MD and Hodgson SV (2003). Fanconi anaemia. J. Med. Genet. 40: 1-10.

Toraldo R, Canino G, Tolone C, D'Avanzo M, et al. (1998). Variable response to the diepoxybutane test in two dizygotic twins with Fanconi's anemia and flow cytometry for diagnosis confirmation. Pediatr. Hematol. Oncol. 15: 45-54. 